\title{
Canadian Unity and Quebec in 1942: \\ A Roundtable Discussion among John Humphrey, Hugh MacLennan and Émile Vaillancourt
}

\author{
by A. J. Hobbins
}

\begin{abstract}
In November, 1942, the CBC broadcast a programme entitled "Canadian Unity and Quebec" across the national network. Set during the divisive background of the Conscription Crisis, this programme was a discussion between three Montrealers - John Humphrey, Hugh MacLennan, and Émile Vaillancourt - who attempted to explain the position, problems and aspirations of Quebec within Canada. Vaillancourt subsequently published the final text of the broadcast, based on the script that the CBC regulations required for such a broadcast. John Humphrey presented McGill University Libraries with an earlier, much lengthier, version of the script which he found amongst his papers and it is published in this article for the first time. The script and annotations, along with other evidence, provide new insights into how the broadcast came about and how the script was developed. In fact, Hugh MacLennan wrote the entire script, based in large part on the ideas of the other protagonists, almost in the form of a one-act play complete with some stage directions. The ideas expressed are important for an understanding of the Canadian unity problem in the mid-century, and still have some relevance after fifty years.
\end{abstract}

En novembre 1942 la CBC diffusa à l'échelon national, une émission radiophonique intitulée "Ul'Unité canadienne et le Québec'. Avec pour toile de fond la crise de la conscription, cette émission consistait en une discussion entre trois Montréalais, John Humphrey, Hugh MacLennan et Émile Vaillancourt, qui tentaient d'expliquer la position, les problèmes et les aspirations du Québec au sein du Canada. Vaillancourt publia peu après le texte définitif de l'émission, basé sur le script exigé par les règlements de la $C B C$ visant une telle émission. John Humphrey fit don aux bibliothèques de l'Université Mc Gill d'une version antérieure du script, nettement plus détaillée, qu'il découvrit parmi ses papiers et qui est publiée dans le cadre de cet article pour la première fois. Le script et les annotations qu'il comprend, alliés à d'autres renseignements, montrent sous un jour nouveau la genèse de l'émission et l'élaboration du script. En fait Hugh MacLennan, en se fondant en grande partie sur les idées de ses opposants, écrivit seul le script auquel il donna pratiquement la présentation d'une pièce en un acte, allant jusqu'à fournir quelques indications scéniques. Les idées qu'il contient sont importantes pour saisir la nature du problème de l'unité canadienne au milieu du siècle; cinquante ans plus tard, elles sont d'ailleurs tonjours d'actualité.

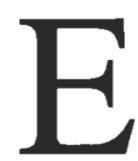

lspeth Cameron, in her notable biography of Hugh MacLennan, devotes some attention to a radio broadcast the author made prior to writing Two Solitudes.' Cameron describes this episode as follows:

Canadians who tuned their radios to the national network at five p.m. on Sunday, 29 November 1942 , heard a roundtable discussion called 'Canadian unity and Quebec.' In a flat, somewhat nasal voice, coloured by the remnants of an Oxford accent, Hugh MacLennan aired his views on what was popularly called 'the French problem' with John P. Humphrey, a professor of international law from McGill University, and the FrenchCanadian author and lecturer Emile Vaillancourt. As the discussion got under way, he found himself more or less in the middle, sympathetic to both English and French points of view: like Humphrey, he was obviously part of the English-speaking élite in Quebec, but because of his loyalty to his Nova Scotian background he also identified with the underdog position expressed by Vaillancourt.

Cameron goes on to draw a variety of conclusions about the debate and its influence on MacLennan. 


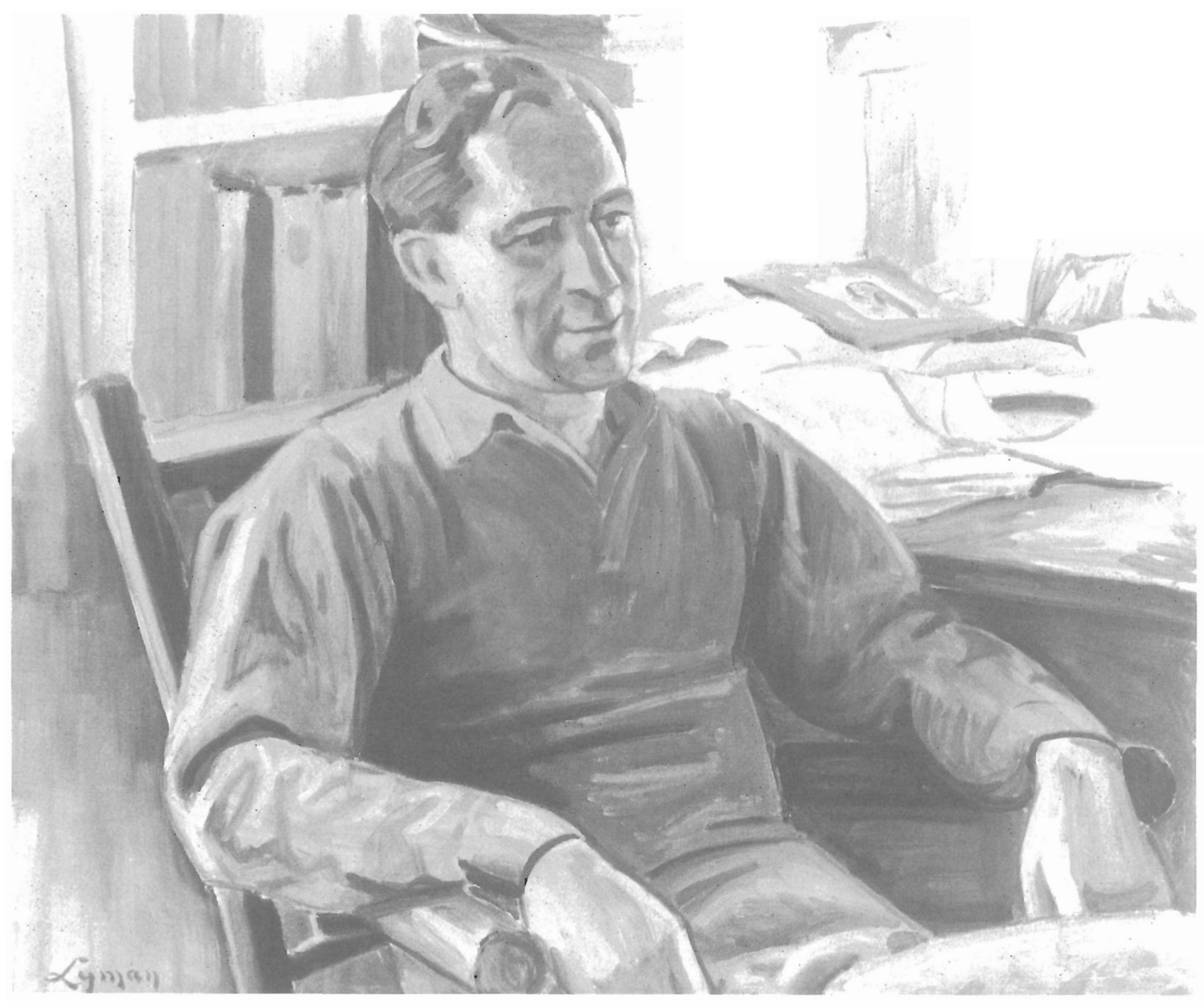

Hugh MacLennan

Photograph of the protrait by John Lyman, 1946

(Hugh MacLennan Papers, Department of Rare Books and Special Collections, McGill University Libraries) 


\section{Canadian Unity and Quebec in 1942}

Cameron argues that MacLennan had, a few months previously, developed the thesis that Canada had to become a real nation if it were to have a national literature, that provincial loyalties appeared to supersede national allegiance, and that Canadians were naturally cautious because of the military defeats of the three founding peoples - English, French and the Scottish Highlanders. He used the trialogue with Humphrey and Vaillancourt, the three of them apparently representing these three founding peoples, to further his ideas, to suggest that Canada's national purposes would be "to provide proper social security for our people". ${ }^{2}$ Cameron also notes MacLennan listened to and learned from the ideas of the other two participants, in particular Vaillancourt, about French Canadian perceptions of the rest of Canada, and the difficulties they experienced therein. He was able to incorporate some of these ideas in his projected novel.

Judging from what Cameron wrote, it is uncertain whether she listened to a tape of the broadcast, read a transcript, or both. She mentions the sound of MacLennan's voice, while in the footnotes she refers to a written transcript. ${ }^{3}$ Cameron's conclusions are supportable were one to assume, as is strongly implied in the transcript, that the radio broadcast was a form of debate between three residents of Quebec, of dissimilar ethnic backgrounds and of differing opinions. Indeed, since this episode represented only a tiny slice of Cameron's immense piece of research, it is not surprising that she took the transcript at face value. Yet to accept this assumption would be to view the broadcast in isolation and ignore the circumstances that surrounded it. A closer examination of these circumstances, and access to certain unpublished manuscripts, would reveal, in fact, that the broadcast was a carefully choreographed and well-rehearsed performance, designed for a specific purpose. Its evolution, from inception to performance, makes a fascinating history.

\section{THE PARTICIPANTS}

Some background on the three protagonists is essential to understanding the story. At this time Hugh MacLennan (1907-1990), later a Professor of English at McGill University and a renowned novelist, was a high school teacher who had just seen his first novel,
Barometer Rising, published the previous year. He had spent the first twenty-two years of his life in Nova Scotia, before going to Oxford in 1929 as a Rhodes Scholar and then to Princeton, completing his $\mathrm{PhD}$ in 1935. Though clearly MacLennan was academically exceptional, the only position he could find upon completion of his studies was head of the Latin Department at Lower Canada College, a private school in Montreal. He held this post from 1935 until the publication of Two Solitudes in 1945. In 1936 he had married Dorothy Duncan (1903-1957), an author of some note, who, in 1942, had more publications than her husband. There is little doubt that MacLennan resented his situation at Lower Canada College, basically then a school for wealthy anglophones, when he felt, with much justice, that his talents suited him for so much more. ${ }^{4}$ His inability to speak French, which he considered his severest educational handicap ${ }^{5}$, restricted him socially to the English side of Montreal and, other than Vaillancourt, he knew only two FrenchCanadians. ${ }^{6}$ The first, a colleague at Lower Canada College, S.E.H. Peron, was a Protestant working in an anglophone environment and thus scarcely typical of the average French-Canadian. The second was a retired farmer, who helped with odd jobs at MacLennan's North Hatley cottage. ${ }^{7}$ MacLennan spent much of his spare time discussing current events, principally with people from McGill University, or playing tennis, at which he excelled, at the Montreal Indoor Tennis Club on Atwater Avenue. ${ }^{8}$ For Hugh MacLennan in 1942 , life could be said to be both limiting and frustrating.

Cameron described Émile Vaillancourt (1889-1968) as an author and lecturer, using the modest description he himself had placed on the published transcript of the broadcast. In fact, he was much more than this. Vaillancourt was an eighth generation Canadian, a descendant of Robert Villancourt who came to Canada from his native Normandy in the mid-seventeenth century. His father, Janvier-Arthur Vaillancourt, was President of La Banque de Hochelaga (later La Banque Canadienne Nationale) for eighteen years, as well as a director of the Imperial Munitions Board in the First World War. Vaillancourt received a Jesuit education in Montreal, a doctorate from the University of Caen and became a Laureate of the L'Academie française. Fluently bilingual, his somewhat varied career included the following: journalist with La Patrie in 1907, director of Thomas Cook and Sons (1921-1927), 


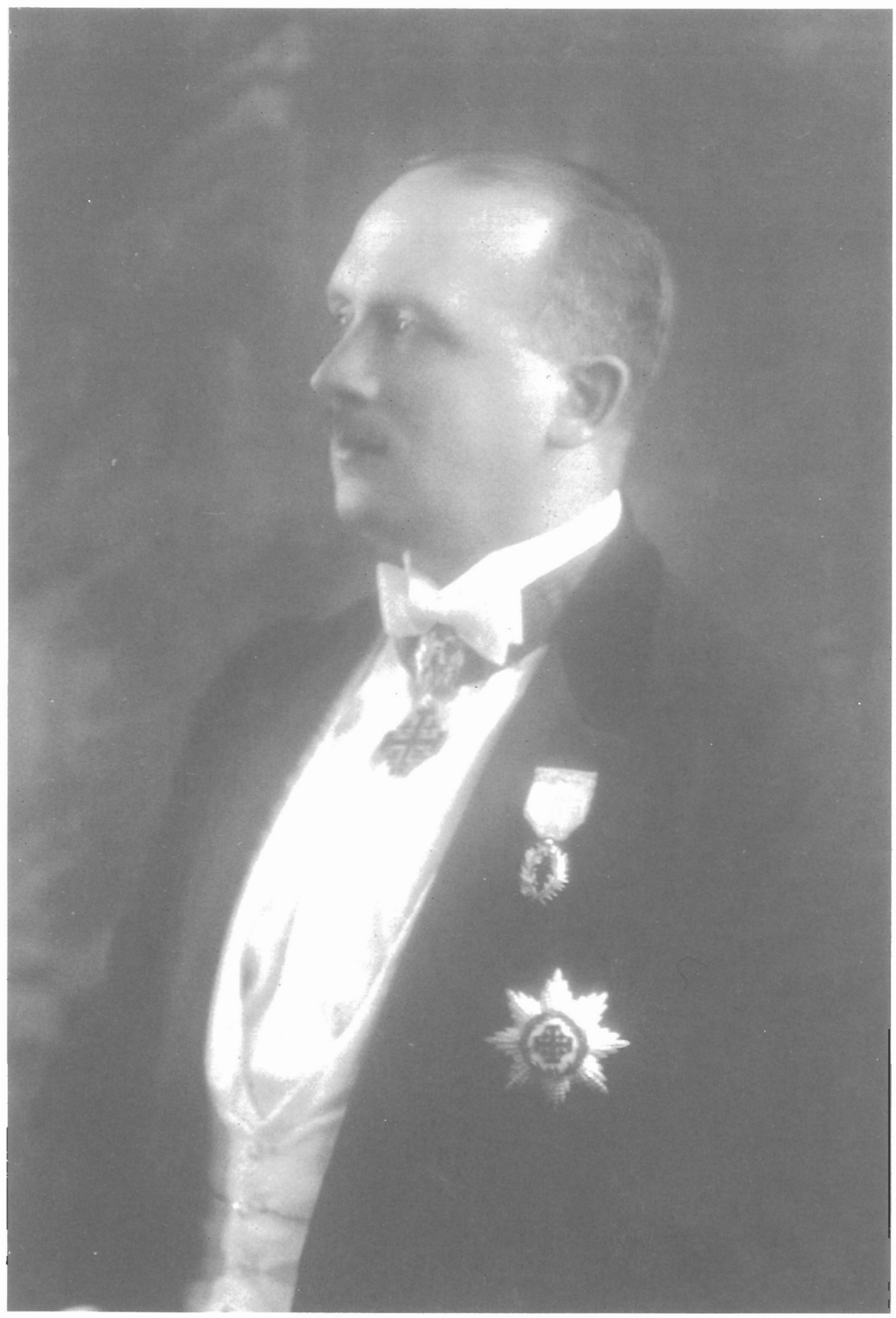

Émile Vaillancourt, ca. 1940. (Courtesy of the Bibliothèque nationale du Québec) 
professor at the University of Montreal and L'École des Beaux-Arts. He then joined the Tourist Section of the Quebec Department of Roads, and subsequently managed the Montreal Tourist and Convention Bureau (1936-1940), in which his duties included being the chief organizer for the state visit of King George VI. He was a prolific author and pamphleteer on a number of subjects, although his most passionate interest was the contribution of the French-Canadian to North America prior to the British conquest. By 1942, his prodigious activities had been recognized by many honours and awards from the academic and public spheres. After the Second World War he was appointed Canadian Ambassador to Cuba (1945-1948), Yugoslavia (1948-1950), and Peru (1950-1955). While his diplomatic career can be viewed as an appropriate governmental acknowledgement of his contributions to the country, it has also been suggested ${ }^{3}$ that his penetrating criticisms of the record of those in power made it desirable to have him exercise his energies and talents abroad for a decade. At the time of the broadcast he appears to have been engaged in working, possibly as Executive Director, with the Quebec Division (which he founded) of the Health League of Canada. ${ }^{10}$

John Humphrey (1905- ) was born in Hampton, New Brunswick. His early years were marred by tragedy: when he was a year old his father died, his left arm had to be amputated when he was six, and his mother died when he was eleven. He was sent to boarding school at Rothesay Collegiate, not far from Hampton, by his guardians. It was intended that, following the standard curriculum, he would take the McGill examinations at seventeen years of age. Humphrey disliked Rothesay so much that he studied in secret for the provincial matriculation examinations, gaining acceptance at Mount Allison University when only fifteen years old. His two years in Sackville were not academically successful but a visit to his older sister, Ruth, then teaching at Baron Byng High School in Montreal, convinced him to try McGill University. In the next six years Humphrey obtained three degrees from three different faculties ${ }^{11}$ at McGill, subsequently obtaining a position as a lawyer with Wainwright, Elder and McDougall. In 1936, Humphrey joined the McGill Faculty of Law at the suggestion of his mentor, Percy Corbett $^{12}$, teaching first Roman Law and then International Law. He became fully bilingual during several study leaves in France, on one of which (1929) he met and married Jeanne Godreau, a French-Canadian from the Gaspé. The Humphreys had two principal social circles. First Humphrey was active in the pioneer socialist circles of the day, being a member of the League for Social Reconstruction, which included F.R. Scott ${ }^{13}$, David Lewis ${ }^{14}$, Frank Underhill ${ }^{15}$, Eugene Forsey ${ }^{16}$ and their like, and Jacques Biéler ${ }^{17}$, at whose Laurentian cottage they often met. Secondly there was the Montreal artistic community which flourished under the guidance of John Lyman ${ }^{18}$ and eventually formed the Contemporary Art Society of Montreal. This was a remarkable group of anti-Academy painters and friends, that included Goodridge Roberts ${ }^{19}$, AndréCharles Biéler ${ }^{20}$, Jori Smith ${ }^{21}$, Philip Surrey ${ }^{22}$ and Marian Dale Scott ${ }^{23}$. Many couples in the Lyman circle were, like the Humphreys and Lymans, an alliance between French and English, and the group existed in a happy climate of bilingualism and biculturalism. lndeed, in this "somewhat Bohemian group", Humphrey noted, "there were no "two solitudes'". ${ }^{24}$ After the Second World War, Humphrey became the first Director of the United Nations Division of Human Rights, in which role he was one of the architects of the Universal Declaration of Human Rights. After his retirement in 1966, he returned to the McGill Faculty of Law where he still teaches.

It can be seen even from these brief biographical sketches of three exceptional and distinguished Canadians that they probably did not quite fit the roles that they ostensibly took in the broadcast. The wealthy, well-educated, bilingual and sophisticated Vaillancourt could never have experienced the difficulties that all too often faced the majority of French-Canadians in the rest of Canada. At ease with captains of industry and kings alike, Vaillancourt would have been accepted anywhere. The guise of an arrogant, unilingual, English-speaking Quebecer, living in Westmount and working on St. James Street, heedless of the French about him, seems scarcely appropriate for Humphrey, a leftist lawyer and academic, bilingual, married to a French-Canadian, and thoroughly immersed in the culture of both societies. Finally how could Hugh MacLennan, descendant of the third group of "defeated" peoples, the Scottish Highlanders, show a greater understanding and sympathy for the French position than the English Quebecer merely because he grew up in Nova Scotia? lronically the "English Quebec" representative, 
Humphrey, was born and spent about the same amount of time in the Maritimes as MacLennan had, the difference being that Humphrey became bilingual after he came to reside in Quebec. Since the backgrounds of all three were so different from the roles they played in the broadcast, it becomes apparent that they did not meet by happenstance at the $C B C$, expressing their views spontaneously. Something of a more contrived nature must have taken place that day.

\section{THE BACKGROUND}

In 1940, Humphrey published an article in the Canadian Forum entitled "Whither Canada?". ${ }^{25}$ Vaillancourt was so impressed with the content that he contacted the author. ${ }^{26}$ Despite their difference in age, they quickly became firm friends, having many ideas in common. Above all they shared a vision of a bilingual and bicultural Canada, in which both founding races would be full participants. They were both federalists, believing their vision could only be achieved by a strong central government, and disliked the parochial attitudes created by regionalism. They discussed and elaborated their ideas many times in each other's homes, agreeing that the low opinion in which Quebecers were held by the rest of Canada was illconceived, and that French-Canadians were inappropriately and unjustly treated outside their province. The antagonism between the English and French was especially evident during the conscription crisis of the Second World War. In April, 1942, the Canadian government held a plebiscite asking the electorate to release it from its previous promise not to introduce conscription for overseas service. In English Canada $80 \%$ of the voters said "yes", while in Quebec over 70\% said "no". As a result Quebec was considered a hot-bed of disloyalty by some Anglophones and, at the time of the broadcast, there were greater than ever impediments to the vision that Humphrey and Vaillancourt shared.

Humphrey and MacLennan became acquainted under different circumstances. Humphrey never considered himself handicapped, possibly because his amputation came so early in life. He was very self-sufficient and was never deterred from attempting and mastering activities one might initially consider required two arms. To this day, he believes that his greatest feat of "unidexterity" was learning to tie a bow-tie, after which everything else was relatively easy. Amongst other things he played both golf and tennis, developing in the latter a "fast and tricky" serve. He first met MacLennan as a rival across the net at the Montreal Indoor Tennis Club, where a friendship quickly blossomed. It was not long before Humphrey introduced MacLennan and Vaillancourt to each other, and soon all three were discussing their ideas.

\section{THE BROADCAST}

In 1942, the CBC broadcast a series of programmes called "Discussion Club" on Sunday evenings on the national network. The programmes originated from the various $\mathrm{CBC}$ studios around the country. In November, the Discussion Club was focusing on the question of provincial problems. The emission of Sunday, November 22, had come from Vancouver and was called "The B.C. Problem". Montreal was scheduled to host "The Quebec Problem" on the following Sunday. Humphrey, MacLennan and Vaillancourt, all veterans of local broadcasts, were asked to form the Round Table for the Montreal broadcast. They accepted with alacrity, seeing it as a wonderful opportunity to get their message across to English Quebecers and the rest of the country. At this time producers insisted on a written script, which was checked before the broadcast was aired. Speakers were expected to stick to their scripts. ${ }^{27}$

The three protagonists met in Humphrey's apartment to discuss how they would handle the half-hour broadcast and the production of the script. They discussed their ideas and it fell, naturally enough, to MacLennan to take notes and subsequently write the script. This he had typed and mimeographed, and the three met again to discuss the draft. Changes were made by hand, but there was not time to produce further typed drafts. Thus what the listeners heard were the ideas of the three men, rewritten and packaged for dramatic or other effect by Hugh MacLennan. Some of Humphrey's parts even contained instructions 10 state something "(With indignation)" (in support of one of Vaillancourt's home truths) and "(Seriously)" (after MacLennan had made a joke), while Vaillancourt was told to "(Pause)" on occasion. Possibly MacLennan felt such stage direction necessary, fearing 


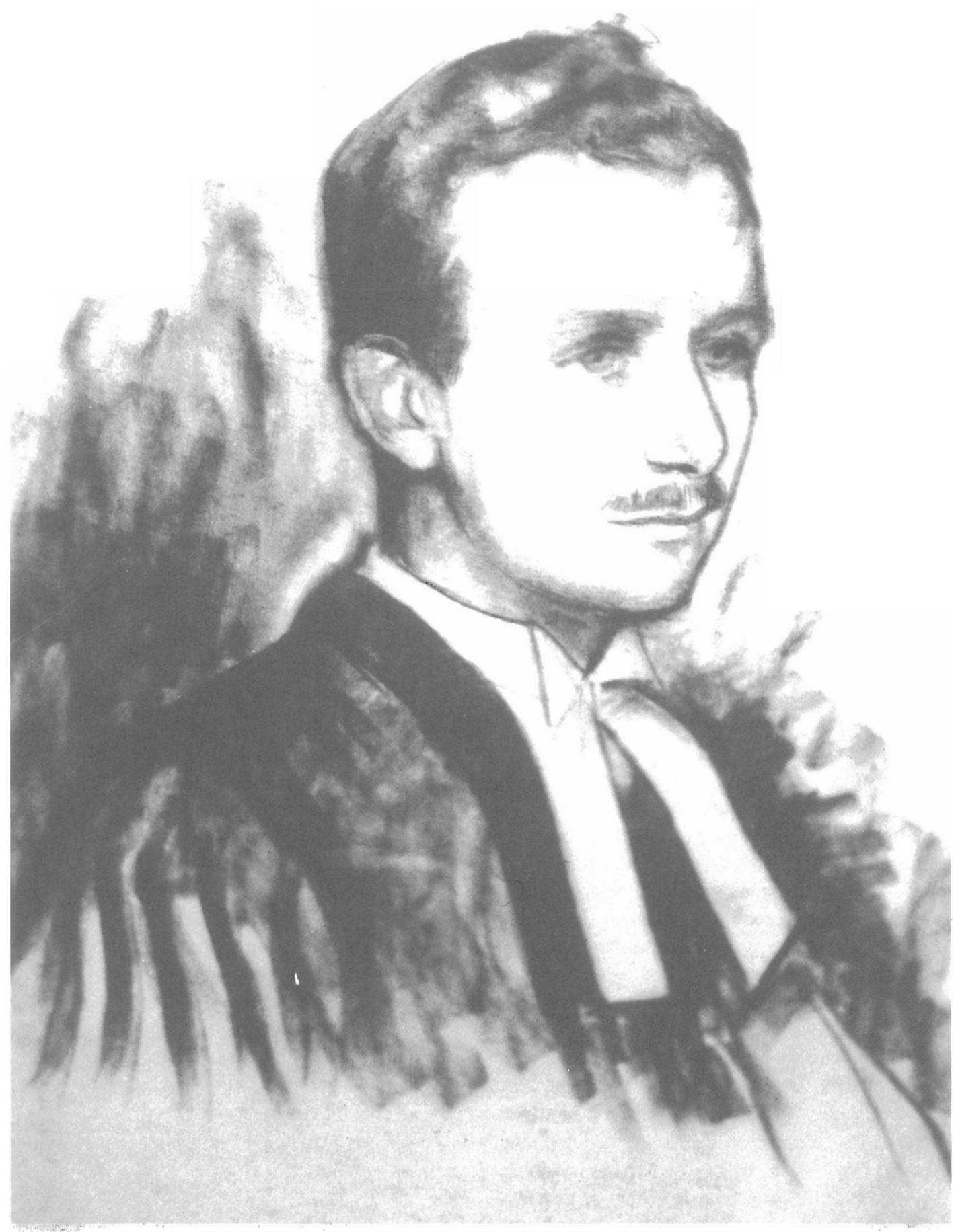

John Humphrey

Drawing by Marjorie Smith, 1934. 
that his collaborators lacked the thespian talents to pull this off without such instructions. The time frame within which all this work was done is evidently less than a week. The mimeograph refers to the broadcast of the previous week and seems to be the only one produced. The three men, therefore, went to the studio with hand-corrected copies of their script.

One at least of the mimeographs survived amongst Humphrey's papers, annotated in his hand. Vaillancourt's was evidently used for the production of a pamphlet, which he had published by the Canadian Printing and Lithographing Company. Vaillancourt later bound this pamphlet with a reprint of an article by F.R. Scott and the text of one of his own speeches, publishing them as a booklet entitled The Canadian Problem (Montreal, 1942). The three friends had entitled their broadcast "Canadian Unity and Quebec", and Vaillancourt used the same title for the pamphlet. Cameron almost certainly used this pamphlet, guessing understandably but erroneously from the rather obscure title page information, that it was a publication of the CBC. MacLennan's copy does not appear to have survived. ${ }^{28}$

Vaillancourt produced the pamphlet from the script that he had amended, but it differs very little from the changes that Humphrey had made to his. The pamphlet is rare, but photocopies are easily obtainable from libraries which hold it. Humphrey's script is, however, unique and important for a number of reasons. First, MacLennan's original draft is significantly longer than the final text, and thus included more of the three men's ideas and concerns. There would be a number of reasons for the cutting back the original, as follows: time constraints of a half-hour broadcast; disagreement with MacLennan's interpretation of what they felt; second thoughts about the wisdom of making certain statements; and possibly even because a statement may have been perceived to be too dishonest to the listener. Secondly, it could be said to be an undiscovered literary manuscript, a one-act play by one of Canada's foremost novelists. Thirdly, it sheds some light on the relationship among the three men that is lost in the final version. In the broadcast it was apparently decided that they would address each other by sumame only, possibly because it was deemed professional or perhaps to demonstrate a greater distance between themselves than actually existed. In the original script Humphrey is called "John" by the others, and uses their forenames "Hugh" and "Émile" - in exchanges between the others it is always "Mr. MacLennan" and "Mr. Vaillancourt". This would surely show Humphrey to be the link between the unilingual English Quebecer and the bilingual Francophone, and that the latter two did not yet know each other well. In the broadcast, Humphrey, if he were playing the part of the English Quebecer, was only playing the role MacLennan assigned to him. Perhaps the role was felt to be a dramatic necessity for the English, French and Highland Scottish analogy MacLennan introduced. Finally, it shows MacLennan to be the source of the mimeograph, as the misspelled name "Humphry" appears on the front in the novelist's handwriting.

It is quite clear that, regardless of the roles MacLennan appears to have assigned to Vaillancourt and Humphrey, or the words he might have put in their mouths, both were delighted with the final product and felt that it represented the essence of what they wished to communicate. The fact that Vaillancourt went to the trouble and expense of publishing and distributing the script is an obvious indication of his satisfaction. ${ }^{29}$ Humphrey's view can be found in another source, which also provides corroboration of MacLennan's role in the production of the script. Eight years after the broadcast, he confided to his diary:

\section{October 2 [1950, Great Neck, N.Y.]}

I picked up this evening the little book in which Emile Vaillancourt had printed the text of a radio talk which he, Hugh MacLennan [and 1] gave over the C.B.C. in November, 1942. The subject was Canadian Unity and Quebec. We had a preliminary talk in my tlat; but it was Hugh who wrote the script. The result is pure MacLennan; for while I would have said the things which 1 did, had it not been for Hugh, I would never have said them in the way I did. I must say after eight years, that the broadcast reads reasonably well and that the things we said needed to be said.

It was not until many years later that Humphrey came across the original script. ${ }^{30}$

There is further evidence that the role of writing radio scripts was not unfamiliar to MacLennan. In the 
summer of 1942 he and his wife had purchased their summer cottage in North Hatley. Dorothy Duncan remained there even on occasions when her husband had to go to Montreal, and so listened to some of his broadcasts from afar. On September 8, 1942, she wrote ${ }^{31}$ to him:

I heard your programme last night. ${ }^{32}$ Didn't know what time it came on, and my only radio, programme time-table didn't show it, so 1 just kept CBM on all evening. And then suddenly I heard a fine voice reading your unmistakeable words. Swell way to open it. Your own voice was pretty well distorted, however. Not bad, but not as good as your previous broadcasts, because the engineers had their instruments set for the announcer's tones, and even Alex Sim ${ }^{33}$ sounded not too good. I thought it was a very good introduction to the series, and certainly you got a lot of publicity out of it. Also... it is very wise indeed for someone else to act what you write. Otherwise, it would be too much of your own personal opinions leading people... or it would seem to be that. Eileen [sic] Ross ${ }^{34}$ sounded best, incidently. She has a fine voice for the radio.

\section{THE SCRIPT}

In view of the importance of the script and, indeed, its cogency to contemporary events, it will be reproduced here in full. This is made problematical by the fact that there are really three documents: the original mimeographed script, the handwritten annotations, and the published version. The following editorial techniques are employed: the original material that remained untouched will be given as straight text; text that was crossed out will be left in its original position but shadowed; handwritten annotations will appear in italic print; if the handwritten material replaces crossed out text the italic print will immediately follow the shadowed tex; distinctions between the final script and the printed version will be footnoted only if they appear to be significant. Using these guidelines it should be easy for scholars to reproduce both MacLennan's original text and the handcorrected version, although it will not, of course, read easily. In the printed text, surnames with no designation are used without exception, but this usage is only reflected in this transcription where Humphrey made the change by hand.

\section{Humphry CANADIAN UNITY AND QUEBEC}

November 29th, 1942.

Announcer's Introduction:

Speakers: Mr. Emile Vaillancourt

Professor John Humphrey

Hugh Maclennan

Time: Sunday, November 29, 5 P.M.

H. Well, gentlemen -.- before we get down to this discussion -- I think we'd better remind ourselves that we're talking to the rest of Canada this afternoon. And if for three men from the Province of Quebec to try to do anything like that -- especially at the present time -- it pretty well puts pen them on the spot.

M. After listening to the broadcast in this series from British Columbia last Sunday afternoon, I gathered we were on the spot even before we came down to the studio. How did you feel about that, Mr. Vaillancourt?

V, Oh, I'm a native French-speaking citizen of Quebec -- and of Canada. So being put on the spot by the other provinces is hardly a new experience for me.

M. Well -- I grew up in Nova Scotia -- so perhaps I can understand how you feel.

V. Yes.. perhaps you understand a little how I feel. But your case is different, just the same. A good many of the other eigh ${ }^{35}$ provinces of Canada seem to us French-speaking Canadians to have a very special spot reserved to put us on. So when you from the Maritimes, Mr. Maclennan -- and 
when you, John -- an English-speaking citizen of Quebec -- hear people in Ontario or in British Columbia speaking about what they call "The Quebec Problem" you don't feel it in your hearts the way we do, and I don't see how it can hurt in quite the same way.

H. No, Swule Vaillancourt, perhaps it doesn't. But it's beginning to hurt. It makes mo thorrughly angry when I Nothing annoys me more than to hear loose talk about the so-called "Quebec Problem". And it's been my experience to discover that those who use the words the most, understand the least what they're talking about, and what they mean by them.

M. I completely agree with you, John. As a born Nova Scotian I [am] able to know that sectionalism has been the curse of this whole country. If there's a separate "Quebec Problem", there's also a separate "Ontario Problem". And if we keep harping on this point of view, it won't be long before we've invented for ourselves an "Eskimo Problem". So let's at least talk about a Canadian Problem. Let's think about Canadian unity. Can we say it's ever existed in the past? Can we say it's ever likely to exist in the future?

V. You mean -- is Canada a nation?

M. That's about as simply as the question can be put. The amount of honest doubt at large in the Dominion right now proves that the nationhood of Canada is not something everyone takes for granted. If it were, we wouldn't be on the air right now. After all, people don't argue about established facts?

V. I know a lot of people who spend all day arguing about established facts.

M. So do I, Mr. Vaillancourt --- But the CBC doesn't use the tax-payers money to let them do it over the air.

H. Well -- before we begin arguing about anything - we'd better do some defining of terms first...
M \& V. By all means.. That's essential... etc.

H. First of all -- let's agree on what we mean when we use the term "nation". Would you venture a definition, Emile?

V. There are obviously several definitions possible. Perbaps if we look at thern al, we can hinally. agree on what we ro talking about. 98 . 10 begin with - some people might say that a nation is an independent body of people living within Gefined boundaries under a law accepted throughout all their territorias.

H. On that definttion, Canada wotild certainly be a nation. firt I would never accept that 8 s describing a nation at all. That's the definitton of a state

V. Exactly - for the Law to toesit necessanly rouct the spirit of a people at all: Surely "nation" is a sociological term, not a legal one? What's your idea on this, Mr Maclennan.

M. Well -- a nation seems to me a body of people, living together, with what might be called a collective point of view. In great issues, that point of view tends to become unified. It's what gives a people its national personality. for instance - the figure of lothn butl eontains something of the personality of England:

H. And in Canada our cartoonists have nothing better to fall back on than pictares of Mounied Policemen 2 o, Then I'm afraid we've got to admit that no one has a clear picture in his mind when he uses the term "Canadian". And because there is no clear picture -- because to date Canadians have never seen themselves clearly in the glass -- our country lacks a clear-cut personality. You can $\mathrm{sec}$ that lack of a personality in our politics.

V. The tragedy -- if I may use so strong a word -is that the provinces understand themselves, but they have never been willing to go very far towards understanding each other. But you haven't given us your definition, John! 
H. Some say that for a country to be a real nation -and not merely a geographical expression -- it's necessary for it to have a common language and a common race. But I believe that's wrong. Certainly it would rule out Canada.

V. You're right .. that definition is too narrow. Look at Switzerland - with three, even four, languages and three distinct races. And yet Switzerland is the oldest and soundest democracy in Europe. Look at the Soviet Union. - ${ }^{36}$

H. Yes .. to limit "nationhood" to a common language and race makes the definition far too narrow. But what of a common history? Don't you think that might be nearer the truth?

M. It would be nearer, John, but it wouldn't be the whole truth. And applied to Canada it doesn't get us very far. The races that make up Canada have something of a common history ${ }^{37}$, but Wolfe and Montcalm hadn't much in common at the Plains of Abraham. And since the Quebec Act there hasn't been much time for our national history to solidify into a genuine national legend.

V. I don't entirely agree with you there, Mr. Maclennan. Our Canadian history goes back at least as far as the history of the United States. And in French-Canada, it goes back a lot further.

M. Yes, but with a difference. The United States found its nationhood through a successful revolution in the late Eighteenth Century. We Canadians pride ourselves on our loyalty at that period -- which means loyalty to a colonial status. Besides that, the three principal races which formed the original Canada - the French, English and Highland Scotch - . had all been defeated in war. The French-speaking Canadian has never forgotten the Plains of Abrahan, but the English and Scotch have ofter forgotten that thetr ancestors became Canadian on account of military defeats, too:

H. Well, I suppose the Empire Loyalists were defeated. At least, their side lost the American Revolutionary War: And after the Battle of Culloden the Highlanders pretty well had to leave
Scotland or starve. Are you suggesting that the only thing that the original Canadians liad in common was the fact of their all having been on the losing side in war?

M. At least it's one of the things they had in common. And we too easily overlook the way: that background affects our actions today. So far as 1 can see, it's the only thing that explains why all of us know what we're against before we know what we're for. In elections we usually prefer to vote against someone, instedd of for someone.

V. But in spite of these defeats, Canada was settled. And now Well I'd like to say something that we in Quebec feel the other provinces too readily forget. I'd like to repeat what Stanley Baldwin said in Toronto, in April, 1939. This is what he said: "Let Canada never forget that it was the loyalty of Quebec in the American War of Independence .. and subsequently .. that settled the future destiny of Canada, and makes her nationhood a reality today. Two languages.. two cultures. two great religious branches.. united to form Canada.. and she found unity and freedom". .38

H. The original part of Lord Baldwin's statement -that Canada would not even have had a chance of becoming a nation had it not been for the part played by Quebec -- is obviously true. But Enile -- do you really accept the latter part of his statement?

V. I wish I could -- But no, it's not possible to accept that. We haven't found true unity yet. And it does our country no good to pretend we have. I believe we're making progress towards finding it. But I must say this .. To many French-speaking Canadians it doesn't look as though we'd all found equal rights and freedom. And if we're ever going to have that grand union of races that the orators like to talk about in Canada .. both races must have equal rights!

M. I'm glad you've made that point, Mr. Vaillancourt. 
H. Yes, Emile -- the rest of Canada has got to realize that at the present moment the Frenchspeaking Canadian simply doesn't believe he gets a square deal.

V. Perhaps that's putting it a little strongly. In the Province of Quebec -- in our old home -- we are content enough. But in the other provinces -(PAUSE) gentlemen, if you were a Frenchspeaking Canadian -- a poor man -- looking for a job in Ontario -- l'm afraid you would soon understand that your race -- in itself -- would make it hard for you to get the kind of work you wanted. I'm sorry to have to say this over the air, but ..

H. (With indignation) Every honest man knows it's true. And the reverse of the picture doesn't hold good in Quebec, either. Look at the English minority in Montreal and other parts of Quebec itself -- Nobody who walked down St: James street lives in Westmount as I do could say that the English-speaking minority in Quebec doesn't get a fair chance to earn a living.

M. Well, John Humphrey -- to get you away from St. James Street Westmount for a moment -- I'd like to go back to this matter of definition of nationality. You know, at the present moment Canada is like a woman with two men courting her. Both those men think their future wife should be just like themselves. But she the two men happen to belong to different races, they have different values in life, and they go to different churches. And because they are $\underline{\mathrm{so}}$ different -- well the woman hasn't made up her mind yet, and the marriage hasn't taken place.

H. If that sums up the situation we're at a total impasse. Now I think...

M. Don't push me too far with that metaphor or you'll have me recommending a design for living, and then the engineer will cut the lot of us off the air.

H. (Seriously) I think I've hit on the only definition of nationhood that can possibly apply to Canada. Here it is, and you can tell me what you think of it. Canada can become a true nation -- a real unity -- on one condition only. That is, if we -in Canada -- achieve something of a common national purpose.

V: That's splendid, John. ${ }^{39}$ That's what l've been hoping and working for to produce for years. ${ }^{40}$ A common national purpose. The future can be better than the past only if we have the will to make it so. In Canada we've looked at the past too often and too long.

M: It's certainly not an accident that most of our Canadian novels are historical novels.

H: Or that the motto of Quebec is "Je me souviens".

M: But what about the war?... Haven't we perhaps a common purpose now in the war?

H: A common purpose to defeat the Axis? Of course. Except for a very small minority of very noisy people -- all Canada is Canadians are agreed on that. And they also agree that this war is not an imperialistic war...

V: In spite of what some people in other provinces seem to think, Quebec knows that this is not an imperialistic war. Quebec is in this war -- and her purpose is and her contribution are is far greater than the rest of Canada realizes.

H: You're right about that, Enile, and l'm glad you've said that it. But to return -- the winning of the war is not the kind of common purpose I had in mind. After all, we share that purpose with every one of our allies among the United Nations. ${ }^{41}$ And we in Quebec have to face th. fact.. . the way the war propaganda has been handled in Canada has not strengthened our mational unity at all. In fact, last year it nearly strained it beyond endurance. Speaking of the war, the reason it has not become the common purpose that it could have been is that our psychology has been all wrong from the beginning.

M: Wasn' That because the war was presented to the Province of Quebec in the worst way possible? 
Wasn't that because of course, for the government is still presenting the war to us in terms of commercial advertising. Therefore they acted as though the war had to be sold in Quebec. Quebec was made to feel that the moment war broke out as though the rest of the other provinces acted as though they expected Quebec to oppose participation.

H: It goes deeper than that. The original Not only that. We never adopted a national point of view. Our war posters were bad. Our pageantry was all imported. There were no new Canadian slogans or Canadian songs. We had no Canadian songs, for example. ${ }^{42}$

M: There were no new slogans or songs of any kind. 1 returned to Canada from the United States the day after wat was declared. Within ten minutes of being back on Canadian soil I heard a recruiting band playing " $\mathrm{Oh}$, it's a lovely war" ${ }^{\mathrm{t}} \cdot{ }^{4.3}$

H: But to return to the point.. When 1 speak of a Canadian purpose 1 mean a purpose of our own. 1 mean a vision of what sort of nation we want Canada to become.

M: During the last twenty years whatever vision the Fathers of Confederation had has become badly blurred. The trouble is, all visions need renewing. You can't serve the same old thing -warmed-up -- year after year and have it mean much.

V: You're right about that, Mr. Maclennan. In spite of our great achievements -- in spite of building the railroads -- of opening up the west and the northland -- even in spite of the wars we've gone through together -- to us in the Province of Quebec it often seems as though the other provinces of Canada preferred to feel a prior loyalty to England. And for any country to feel a prior loyalty to another land makes a true nationhood impossible.

M: Some Canadians make such an issue out of that prior loyalty to Great Britain, Mr. Vaillancourt, that through their misguided efforts we're the only one of the self-governing dominions without a flag of our own.

V: And a flag of our own would mean a great deal - far more than words can express - to the Province of Quebec.

M: It's part of the hangover from colonialism. Too many Canadians behave as though no purpose we would possibly have in Canada could ever be important.

$\mathrm{H}$ : Or as though loyalty to Canada -- and pride in Canadian nationhood -- and insistence that we discover a true Canadian purpose -- were disloyal to Great Britain -- which is ridiculous.

M: As ridiculous as to consider a boy disloyal to his father for putting on long pants and setting up a home of his own! ${ }^{44}$

V: Now, gentlemen -- I'm going to say something I fear some of my fellow-citizens aren't going to like. But it's got to be said. French-Canada admires and respects Great Britain. She honours the British people and is loyal to their king - and her own. She is giving to this war more than most Canadians credit her with giving. (Pause) But the emotions of French-Canada towards Great Britain cannot be the same as the emotions of some people descended from the British Isles, who live in Canada today. Therefore it is neither fair nor sensible for anyone to expect Frenchspeaking Canadians to feel it necessary to fight merely because Great Britain happens to be at war. There will never be a Canadian national understanding until that fact is accepted and respected. But -- let no one forget this -- Quebec fights now because she believes that England's cause is her own cause and because of humanity. I beg my fellow-Canadians not to believe that the voices of the small group of trouble-makers -those voices which are so eagerly picked up by the equally small handful of trouble-makers in other provinces who want to put Quebec in the wrong -- 1 ask you not to believe that those voices represent the spirit of my province. If French-speaking Canadians give such men an audience, it's mainly because they feel defiant to people in other provinces who slander Quebec. 
So 1 say again. . French-Canada is behind this war now because the great majority of Frenchspeaking Canadians know that theti cause is also the chuse of England. . and of the United Nations. and of all bumanty. And, in my opinion, no lesser cause ss worthy of a war such as the one we fight now:

H: Emile Vaillancourt... you've put the case of Quebec and the war as clearly as I've ever heard it put. Do you agree with that, Hugh?

M: Yes... I think I do. I agree with the statement that the Province of Quebec is behind this war more than the rest of Canada realizes: And it also seems to me that the other provinces overrate the importance of the isolationists here. But Mr. Vaillancourt -- I don't think that mere anger at rude people in other provinces is entirely the only cause of the isolationism that certainly does exist in Quebec.

V: I'm interested in that statement, Mr. Maclennan. Tell me frankly when you first came to Montreal to live... what did you feel was the greatest weakness in the Province of Quebec?

M: The educational system. The other provinces have little to boast about in their educational systems, but in Quebec I think education is relatively weaker than elsewhere.

V: It has been weaker in the past, but at the present moment much is being done to improve it. I suppose you mean that too little attention is paid to a practical curriculum.

M: I mean more besides that. Quebec educators encourage their pupils to dwell too much on the past. I don't mean by that merely an excessive study of history. History can be a modern study... if you use it for guidance in your own affairs. I simply refer to an attitude of mind.

H: As a matter of fact, Hugh Maclennan, Senator Athanase David ${ }^{45}$ made the same point only a few days ago. I'd meant to bring up that point myself and l've made a note of it. "In school books and elsewhere," Senator David said,
"Quebec lives in the past. Why," he went on, "Does the school, the college, the convent, still live the life of yesterday, and not make contact with today's life and that which will soon be upon us?" Now, I admit that's a sweeping statement, but I think there's a great deal of truth in it just the same. What would you say to that, Emile Vaillancourt?

V: It's the gospel l've been preaching for years.

H: But the fault in education is not all Quebec's. Every province tends to be isolationist in some respects to some degree... and the educational system is largely responsible for that isolattonism. After all, it. What do you expect with education entirely in the hands of the individual provinces -- some degree of isolationism is an inevitable result.

M: But in Quebec isolationism provincialism is mainly the result of her a traditional point of view. Isolationism in the other provinces is somewhat different. In most of them it's In other provinces it is chiefly the result of plain ignorance. Quebec may brood too much over the past, but it's a singular fact that she knows the rest of Canada better than the rest of Canada knows her. Ignorance, as Karl Hambro ${ }^{46}$ said in Montreal recently is the privilege of the majority. But if Quebec could realize that half the time what appears to be dislike of herself is really ignorance -- perhaps we would have less friction.

V: I have an interesting little story to illustrate the point. Some years ago I instituted cooperated in the institution of a system whereby I - and certain other French-speaking Canadians of Quebec -- arranged that sons and daughters of ours should spend their vacations as guests of citizens in Ontario. In return the families who received our children sent theirs to us... The scheme worked out splendidly. But when the children came home, we in Quebec discovered that while our sons and daughters had spent a delightful summer, they had not been surprised by anything they discovered in Ontario. The children from Ontario -- on the other hand -- had their eyes opened by what they discovered in 
Quebec.

M: I can well believe it, Mr. Vaillancourt. And -speaking as a native of another province -- I can very truly say that Quebec is so different in its way of life from the rest of Canada that it isn't an easy province to understand. I think it woukd help if Quebec realized that, for it's certainly a fact.

H: Now, gentlemen -- let's try to wind up this discussion - Let's get back to the problem of Canadian unity. We've agreed that it is only through a common purpose that Canada can become a unified nation. Now - Emile Vaillancourt -- could you outline for us what you - as a representative citizen of Queber - have in mind when you speak of a common purpose for Canada to follow after the war.

$V$ : That's a big question, John.. Let me seo... Well, the first thing necessary is to give the world peace after the war, and Canada must have some views on that. 1 give you four fundamental principles for the establishment of an enduring peace. The first is to secure the withering away of frontiers, military, oconomic and social, which divide the states from one another today.

H. Al least Canada and the United States bave made a beginning of that through our joint-defence board and the Canadian-Alaska Highway.

$V$. The next point to to I suggest is a restriction in the absolute sovereignty of individual states. The third point is a revision of all Imperialisms and exploitations in all colonies afl over the world. The fourth is the establishment of a living peace in constant evolution.

H: These points are very well taken, Emile - but it seems to me that Canada, by hersell, can't have the same influence as the great powers. And in the near future, we ma find ourselves with little to say in the establishment of the international post-wat settlements. But when I spoke of a common purpose, I was thinking more in domestic terms $\rightarrow$ a common purpose which is peculiarly Canadian, if such a thing is possible.
V: Then Humphrey. Therefore I'll say nothing about the international aspects of the problem... for that a common purpose to be created ... certain preliminary steps suast first be taken ${ }^{47}$. First... Canada must have her own national flag..$^{48}$ Secondly Also, I would like to see an end to the use of the term "Dominion." According to the old articles of the Church of England, the word "Dominion" was synonymous with colony, possession, or plantation. Canada is not a plamtation.

H: But that the term Dominion was not originally intended to signify inferiority.

V: To many French Canadians - perhaps owing to the suggestion the word gives in the French language - - it does signify inferionity... or at least, colonialism now. ${ }^{49}$

H: But surely, Emile -- those are only symbols. Symbols hardly seem to me so important that..

V: That's just the point the other provinces overlook. They don't realize that the refusal to have a national flag is a slap in the face to the French-speaking Canadian. You speak of symbols - r rightly or wrongly to the FrenchCanadian, The refusal to have a national flag of our own is a symbol symptom of a subservient state of mind and this province will never fully believe that Canada intends wants to become a nation in her own right until the [sic - 'she' intended symbolizes that intention by adopting a flag of her own.

M: You mean, Mr. Vaillancourt - that if Quebec could really believe that the other provinces desired to make Canada a nation in her own right... that a great flood of new energy would be released from here?

$\mathrm{H}$ : Do you mind, Emile, if I answer that question. I certainiy think that would happen. At present there is a great evolution underway in Quebec. The old, established spokesmen of Quebec have always been professional men ${ }^{\text {. }}$. But now we see a change beginning... Engineers, business men, and technicians, and industrial werkers are 
beginning to make their voices heard. There's a lot of new energy to be tapped in Quebec. But Emile Vaillancourt -- I think those symbols you spoke of soon will soon be changed... can you give me something more positive to go with? Something that will give us a real practical purpose?

V: Yes, I can. Any nation is as good as its educational system. I say.. let Canada spend as freely in peace as she does in war. Let Canada spend the money necessary to make good education open to all classes...

M: And to all provinces... Education is starved all over Canada, not just in Quebec.

V: I would say further... Let us teach, in all our schools, the greatness of England and of France. Let us teach the weakness and mistakes of England and France as well. Let us so build our educational system that a boy in Canads Canadian youth may hope to become, not merely a citizens of Canada, but also a citizens of the world.

H: That would be wonderful, Emile---- but it would take many years ... to produce a state of affairs like that:

V: The work of $a$ generations ... But you asked me for a purpose. There would be no point in giving you a purpose that could be accomplished in a few years.

M: And in hard fact, Mr. Vaillancourt -- it would come down first to educating the general public to be willing to spend money on education. You've recognized that of course. But in a country which prides itself -- as Canada does -on the educational system it already has -- and still pays the average teacher less than the minimum wage for unskilled factory labour ... well -- you see how far we've got to go. ${ }^{5 t}$

$\mathrm{H}$ : Emile Vaillancourt has given us his idea of a purpose for Canada. Can you give yours, Hugh Maclennan?
M: What t have to say is an expansion of what Mt. Vaillancourt has said already. Well probably both of you, gentlemen, have pretty much the same idea as the one I'm now going to give you. Canada's individual national purpose after the war has to be very similar to the individual national purpose of every country in the world. In a word, we've got to provide proper social security for our people.

H: We talk about the People's War --- but the talk $a$ People's Wor is meaningless unless it ends in the a People's Peace.

M: President Roosevelt, with his four freedoms, has given us a lead already. Now, of those Four Freedoms -- how many do you think the people of Canada enjoy now, or, have ever enjoyed?

H: Certainly we enjoy Freedom of Religion. Freedom of Speech we enjoy legally except for limitations in war-time. But freedom of speech in peace is curtailed by the fact that the privileged classes generally control the newspapers and the jobs, and apply economic pressure to anyone who talks out of turn.

M. But the last two freedoms freedom from want and freedom from fear --- those are things only a small proportion of Canadians have ever enjoyed. We were have been no worse than some other countries, but notwithstanding, our record in social security is bad something we ought to be ashamed of.

H: An English visitor sutd recently in the Labour Forum that some of our labotir conditions in Canada were medteval - but social security is an enormous problem, Hught. In fact, the lack of Social security all over the world is conditions everywhere were the basic cause of the present war. But I don't see how we can settle that discuss an issue of that magnitude this afternoon. ${ }^{32}$

M: We can't possibly settle this ssue just by talking about it at any time. But it so happen $s$ that in Canada we have something of a blue-print for Social Security already. 
H: You mean the Rowell-Sirois Report? ${ }^{53}$ Do You call that a blue print?

M: Al least its the next best thing to a blue-print: To obtain social sectrity nears blood, sweat and tears, and when I say that I nean blodd, sweat and teart. Privilege never has, and never will, relinquid its grip from the people's throst withoul pretty strong soctal pressture being applied to it. In The Rowell-Sirois report did tay laid the groundwork for the beginning of a social security system in Canada.

$\mathrm{H}: \quad$ Yes, I think it did, even though it didn't 20 may not have gone far enough. It certainly made ono Wital statement: It sald there would never be a satisfactory federal union in Canads it clear that there can be no Canadian uniry until we have a proper standard of wages right across the country... A proper Canadian standard in wages, hours, old-age pensions, health, housing, and security generally.

V: And if I may interrupt, Johin Humphrey, --- it is the lack of a Canadian standard which at present lies at the very root of the difficulty between Quebec and the other provinces.

M: Absolutely true!

V: The average citizen of Quebec sees We know in Quebec that the workers in Ontario get higher wages than he recenves are paid here. He sees We also know that most of the factories in Quebec are owned by English-speaking citizens Canadians. The result is inevitable. He The Quebec worker feels himself exploited.

H: But wouldn't the other provinces say at once that Quebec is the chief obstacle to the achievement [of] social security in Canada is the lower sfandard of living in Quebec?

M: Perhaps I can try to answer that, John. The other provinces would say that and they would be right there would be something in it. But... the other provinces forget the vital point $\mathrm{Mr}$. Vaillancourt just made. They put the blame for this condition entirely on Quebec... on her educational system, on her faith, on her isolation and obsession with the past. But they over-look the fact that privileged men of their own AngloSaxon race have actually acquired a vested interest in the lower wage rates of Quebec. Isn't that what you mean, Mr. Vaillancourt?

V: It's absolutely what I mean, Mr. Maclennan.

H: Well, gentlemen, our time is neatly up. If fad myself left with a great many lhings I ve not been able to say, As a matter of fact - at one thine or another - you have both said a 10 ot of them for me. We came here, perhaps, thinking We were going to get ints an argument. As its turned out, we ve agreed on nearly every single isste we ve raised. So before leaving the air. I d like $10^{54}$ Let me sum up the most inportant pouns the discussion revealed our discussion: First:- Canada can become a nation only if she achieves a common purpose in perco fime.

Second:- For that purpose to be achieved the other provinces must try to understand Quebec at least as well as Quebec understands them. And Quebec, for her orat must be willing on realize that, as thing stand, she is the most difficult part of Canada to understand.

Third:- French-speaking Canadians must be granted equality of opportunity all over Canada.

Fourth:- We must show that our colonial dependence is ended by adopting a mational flag flag of our own. This does not mean dropping the Union lack. It means appending a Caradian emblem to the Jack, as the other Dominions append their erbblems to the flag of Great Britalts.

Lastly: We must translate President Roosevelt's Four Freedoms into action in Canada. If we do so, we shall be on the way to atfaining Social Security in Canada

M: And it is my contention that If we have even the legitimate hope of social security in Canada, our sectional differences will wither away. 
V: If Canada lacks anything today, it is a clear vision of what she wishes to become. I believe firmly that a genuine vision of social security would not only unify Canada, but would release such a flood of energy from all nine provinces that discussions like ours this afternoon would become meaningless unnecessary.

\section{CONCLUSIONS}

Cameron concluded, as noted earlier, that MacLennan used the views expressed by Humphrey and Vaillancourt to further his understanding of the FrenchCanadian perception of English Canada, an understanding he used in writing Two Soliludes. She is undoubtedly correct in this, although it is clear that the relationships went far further than a half-hour debate in a radio studio. Indeed, had Cameron access to the first draft, she could scarcely have failed to note the coincidence between the two French forenames appearing in the text, Emile (Vaillancourt) and Athanase (David), and those used by MacLennan for the two main protagonists of the first part of $T$ wo Solitudes, Emile Beaubien and Athanase Tallard. Yet to draw conclusions from two sets of established facts can be dangerous.

This danger can be established by examining, for example, what Humphrey heard during the broadcast and relating this to his later activities. Within less than five years of the broadcast, Humphrey was preparing the first draft of the Universal Declaration of Human Rights. In the preamble to this draft he stressed the importance of Roosevelt's four freedoms and he included many articles on social and economic rights. These were both issues raised by MacLennan in the script. ${ }^{55}$ Yet there was no causal relationship between MacLennan's broaching of the issues and Humphrey's subsequent use of them. Nor, given the way the script was developed, can it be concluded with any certainty that the introduction of these concepts was originally MacLennan's idea, merely because he gave himself the lines to speak. These were themes already deeply rooted in Humphrey's beliefs, as were many other issues raised during the broadcast regardless of who the speaker was. In the article that brought Vaillancourt and Humphrey together, the latter had written:
Canadian independence is only possible if we are prepared to think and act in national rather than provincial terms.

... This [the need for central authority] is true, particularly, of all activities which react on the standards of living; for it is essential that standards of living should be maintained approximately equal in all parts of the country.

.. It is not only the separatiste who is suspicious of English Canada. The suspicion is shared to some extent by all French-Canadians. Nor are the reasons difficult to find. The colossal ignorance which most English Canadians have of French Canada, the obstinate refusal of many of then to recognize the implications which result from the dual culture and the fact that approximately one third of the population is French, the undisguised desire of many to have done with this dual culture, their snobbish attitude of superiority,... all these and others have been anything but reassuring to FrenchCanadians. Nor has any effort ever been made to make the latter feel at home outside of Quebec.

. . The problem is largely one of obtaining their [French Canadians] wholehearted confidence; and this can only be done by energetic measures. The first essential is to make the French-Canadians feel at home in every part of Canada. This means that French-Canadians must have the same rights in the rest of Canada as they have in Quebec, and that Canada must eventually become a bilingual country... They [French-Canadians] must be given the right to speak French in the legislatures and courts of every province of Canada; and civil servants, where possible, should be required to speak both languages. More important still, FrenchCanadians, wherever resident in Canada, should have the right to educate their children in their native tongue. And these 
rights must be protected by adequate constitutional guarantees. Add to this a little understanding and good manners, and the attitude of the great majority of French-Canadians towards confederation and the federal powers will change as if by enchantment. Then, perhaps, we can get on with the business of nation building. ${ }^{56}$

In fact, the friendship with Vaillancourt, which stemmed from this article, had a significantly greater impact on Humphrey's international career than any of the ideas that were exchanged during the broadcast. Although Humphrey met Henri Laugier ${ }^{57}$ through Louise Gadbois ${ }^{58}$, an acquaintance from the Lyman circle, it was during many meetings at Vaillancourt's home that they became really close friends. After the war, Laugier became Assistant Secretary-General for Social Affairs at the United Nations and persuaded Humphrey to accept the position of first Director of the Division of Human Rights. It is clear, therefore, that for Humphrey and Vaillancourt the broadcast was not an opportunity to learn from others, but rather a pulpit from which to preach to a large audience a creed in which they both believed. For MacLennan, it may have provided an occasion for both preaching and learning.

Fifty years ago it seems that Canada was in crisis. English Canada appeared to mistrust and exploit Quebec, while French Canadians apparently resented these attitudes and believed they were treated as second class citizens. Unity seemed far away. Three gifted and intellectual Montrealers, committed to a bilingual, bicultural Canada and to a just society, studied this problem and proposed solutions to the rest of Canada. In brief, they proposed that Canada develop a national purpose, one part of which would be to bring social security to its citizens, that Canada throw away the symbolic trappings of colonial dependence, that Frenchspeaking Canadians be granted equality of opportunity all over Canada, and that Roosevelt's four freedoms be translated into action in Canada. Now, after two generations, it would appear that all these things have come to pass, except that any sense of national purpose still appears to lack clarity and universal acceptance. Did the attitudes of Quebecers change towards confederation "as if by enchantment"? Possibly, although not perhaps in the way Humphrey, MacLennan and Vaillancourt had envisioned the metamorphosis.

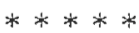




\section{Notes}

The author is grateful to Professors Alec Lucas, Brian Young and John Humphrey, as well as my colleague, Kathleen Toomey, for their comments on this article.

1. Elspeth Cameron, Hugh MacLennan: a Writer's Life (Toronto: University of Toronto Press, [19811), Chapter 6, 165-175.

2. Cameron, 166.

3. Cameron, 390. Cameron lists the transcript as Canadian Unity and Quebec (Montreal: CBC Pamphlet, 1942), 1-16. However, while the transcript accurately reflects what was said, it was privately printed by Émile Vaillancourt and the imprint should read Montreal: Canadian Printing and Lithographing Co., 1942.

4. Cameron, $101 \mathrm{ff}$. Cameron wrote:

In almost every mention of this job he was later to make, his despair at having to take it is apparent. Given his qualifications and the tremendous effort that had been necessary to acquire them, to teach in such a school was far beneath him. (p. 101).

Despite the fact that he hated the place, felt the job was beneath his dignity, and resented the long hours of work required of him for so little money, he did not do a bare minimum of work as he might have. (p. 106).

Cameron does not, however, provide much in the way of documentation to support her assertions regarding MacLennan's feelings for Lower Canada College, beyond quoting his satire of Waterloo School in The Watch that Ends the Night. (p. 104). Her sources are presumably the reminiscences of the novelist and his acquaintances.

5. Hugh MacLennan, "French is a Must for Canadians," Imperial Oil Review (June, 1960), 2-5.

6. Cameron, 169.

7. Cameron's suggestion that MacLennan knew only three French-Canadians is presumably exaggerated. According to Humphrey, for example, the novelist knew Humphrey's wife, Jeanne Godreau, very well.

8. Cameron, 169.

9. By Humphrey.

10. The facts concerning Vaillancourt's life are taken principally from the Canadian Who's Who, but he remains an unusual and enigmatic figure. A career as a travel agent and municipal civil servant would not ordinarily be the background for an Ambassador. Vaillancourt does not appear to have strong poltical connections, but one may speculate that he was probably both independently wealthy and socially well connected.

11. He was to obtain his fourth from yet another faculty, his doctorate in 1945.

12. Percy Ellwood Corbett (1892-1983) joined the McGill Faculty of Law in 1924, after two years as Legal Advisor to the International Labour Organization. He served as Dean from 1928-1936 and retired for heralth reasons in 1942. Recovering, he taught at Yale University from 1943 until his retirement in 1958.

13. Francis (Frank) Reginald Scott (1899-1985), Constitutional lawyer and poet, had been on the McGill Faculty of Law from 1928. He was introduced to Frank Underhill by Percy Corbett in 1931, and with Underhill founded the Cooperative Commonwealth Federation, precursor of the New Democratic Party. See Michiel Horn, The League for Social Reconstruction: Intellectual Origins of the Democratic Left in Canada, 1930-1942. Toronto: University of Toronto Press, 1980.

14. David Lewis (1901-1981) went on to become a Member of Parliament and national leader of the New Democratic Party.

15. Frank Underhill (1889-197I), historian and educator, was a co-founder of the League for Social Reconstruction. His attempted dismissal from the University of Toronto for his leftist opinions and activities was a cause célébre in the annals of academic freedom in Canada.

16. Eugene Alfred Forsey (1904-1991) was a Faculty Lecturer in the Department of Economics and Political 
Science at McGill University from 1929-1941. When he failed to get tenure, he became Director of Research at the Canadian Congress of Labour (later the Canadian Labour Congress) from 1942-1966. In 1970 he was appointed to the Canadian Senate.

17. Jacques Louis Biéler (1901- ) was an engineer and great friend of Forsey. While not a leader in the socialist movement, he provided a link to the Lyman group (see below) through his brother, André-Charles Biéler (1896-1989), a noted Quebec artist. His wife was Zöe Browne-Clayton (1915-1991), a journalist and administrator with both the Montreal Standard and Montreal Star.

18. John Goodwin Lyman (1886-1967) was an enormously influential figure on the mid-century Montreal art scene. Of independent means, he was not only an artist himself but did much to help other artists through holding exhibitions and forming associations. From 1948-1957 he taught Fine Art at McGill University. His wife was Marie Corinne Georgette St. Pierre. In 1945 the Lymans began to spend their summers in North Hatley, and the following year Lyman painted his portrait of Hugh MacLennan.

19. (William) Goodridge Roberts (1904-1974) was, with Humphrey's cousin, Jack Weldon Humphrey, considered the most talented of Lyman's Eastern Group of Painters. Roberts taught art and served as official RCAF artist until he was able to support himself from his work.

20. André-Charles Biéler (1896-1989), older brother of Jacques Biéler, was a renowned artist who concluded his career succeeding Goodridge Roberts as Artist in Residence at Queen's University, Kingston, Ontario.

21. Marjorie (Jori) Smith was at this time married to Joseph Jean Albert Palardy (1905- ), an Americanborn artist whose family moved to Quebec in 1908. Professionally, Smith, who still Iives in Montreal, was always known by her maiden name. Her ex-husband, who became better known as a film director, lives in Paris.

22. Philip Henry Surrey (1910-1990) was a prolific painter, and there have been over one hundred individual or group exhibitions of his work. He was Instructor of Drawing at Sir George Williams (later
Concordia) University from 1965-1975.

23. Marian Dale Scott (1906- ) is a prolific artist, whose works have been exhibited from 1941 until the present day. In 1928, she married F.R. Scott.

24. Ronald St. J. Macdonald, "Leadership in Law: John P. Humphrey and the Development of the International Law of Human Rights," Canadian Yearbook of International Law, Vol. 29 (1991), 27, citing Humphrey's unpublished autobiographical manuscript.

25. J.P. Humphrey, "Whither Canada?" Canadian Forum Vol. 20 (April, 1940), 43-45.

26. This was more than just lip service. When Humphrey wrote his next article in the series "Recipe for Canadian Unity", Canadian Forum Vol. 22 (March, 1943), 345-346, Vaillancourt ensured that it appeared simultaneously in French translation as "Formule pour l'unité Canadienne", Relations Vol. 3 (1943), 34-35. This article, which must have been written before the broadcast even though it was published soon afterwards, contained an elaboration of many of the ideas promulgated in the broadcast.

27. It is unclear whether this requirement was standard policy, or because of wartime censorship restrictions.

28. There is an entry for this title in the MacLennan Papers housed in the McGill University Libraries Department of Rare Books and Special Collections. It was disappointing to discover that this was merely a photocopy of the Humphrey script, which he had sent to MacLennan when he rediscovered it in 1990.

29. Vaillancourt also ensured a French text appeared quickly as "Le Québec devant l'unité Canadienne," Relations VoI. 3 (1943), 16-19.

30. In 1990, Humphrey found the original script amongst his papers. At this time he sent photocopies to both Hugh MacLennan and this writer.

31. Dorothy Duncan, Letter to Hugh MacLennan, September 8, 1942. McGill University Libraries. Department of Rare Books and Special Collections. Ms 466. Correspondence - 1942. File 13, 47. 
32. "Free Lands", the first in the Interamerican University Drama Series, was broadcast at 10.30 p.m., Monday, September 7, 1942, on CBM.

33. Alex Sim was secretary of the Rural Adult Education Service, established in 1938 under the auspices of Macdonald College of McGill University with a grant from the Carnegie Corporation. By 1941, the Service had established seven community schools in the Eastern Townships with nearly a thousand students enroled from sixty-six communities. The Rural Adult Education Service also sponsored Farm Radio Forums to stimulate interest in further study. See Aileen Ross "A Pattern for Adult Education", Canadian Forum Vol. 22 (May, 1942), 50-53.

34. Aileen Dansken Ross (1902- ) is the daughter of J.W. Ross, then a senior partner in the accounting firm of P.S. Ross and Sons. In 1942 Ross had just completed her Master's degree at the University of Chicago. She was a professor of Sociology at McGill University from 1945-1970. Humphrey formed a close friendship with Ross and her brother, Howard Irwin Ross (1907-1974), during his days as an undergraduate in the Faculty of Commerce.

35. Newfoundland was not to join Canada for another seven years.

36. It is perhaps fortunate the participants did not pursue this particular analogy.

37. "... something in common in their history, ..." in the published text.

38. Stanley Baldwin (1867-1947) was in Canada to receive an honourary degree from the University of Toronto, at which time he delivered the Falconer lectures from April $20^{\text {th }}$ to April 22 $2^{\text {nd }}$. These lectures were published as Stanley Baldwin, The Falconer lectures (Toronto: University of Toronto Press, 1939), and Vaillancourt is quoting from the first lecture (pp. 11-12).

39. "That's very good, Humphrey." in the published text.

40. "That's what I've been hoping for and working to produce for years" in the published text.
41. The term United Nations came into common parlance early in the war referring to the Allied powers opposing the Axis. The United Nations Organization, which replaced the League of Nations, drew its name from this usage only in 1945.

42. This was put rather more elegantly in the published text as "... point of view. Our war posters, for example, were bad. There were no Canadian slogans, no Canadian songs."

43. MacLennan is presumably referring to the 1917 music-hall song $\mathrm{Oh}, \mathrm{Oh}$, Oh, It's a Lovely War, see John Brophy and Eric Partridge, The Long Trail: What the British Soldier Sang and Said in the Great War of 1914-1918 (London: Deutsch, 1965), 219. He was perhaps optimistic to expect something more current and Canadian only two days after hostilities started.

44. Putting on Iong pants was then idiomatic for growing up. In the published text the sentence was ended after the word 'pants'.

45. Louis Athanase David (1882-1953) was a lawyer, Liberal Member of the Legislative Assembly of Quebec (1916-1936), and Provincial Secretary (1919-1936). He was summoned to the Senate in 1940. Although David lived very close to Humphrey in Westmount, the extract is presumably from a speech.

46. Carl Joachim Hambro (1885-1964), Norwegian politician, diplomat and author, was part of the Norwegian government in exile from 1940-1945. He was President of the League of Nations General Assembly in 1939 and, during its last sessions, in 1946. Earlier in the year his book How to win the Peace (Philadelphia; Lippincott, 1942) had been published.

47. This phrase did appear in the printed text and was possibly never deleted in Vaillancourt's script.

48. Canada's official flag from 1867-1964 was in fact the Union Jack, not the Red Ensign. However, the Red Ensign with the Canadian badge was allowed to be employed in certain circumstances. Mackenzie King tried twice, in 1925 and 1946, to introduce a national flag, but it was only in 1965 the Maple Leaf became Canada's official flag under Lester Pearson's premiership. 
49. Vaillancourt would provide further details concerning this somewhat esoteric argument in $1 \mathrm{~s}$ Canada a Plantation (Montreal: author, 1944). He asserts the term "Dominion" is synonymous with colony, possession or plantation based on a judgement of Lord Chief Justice Mansfield (Court of King's Bench, English Reports, vol. 98, pp. 848, 1045, Campbell versus Hall, 1774) and Article XXXVIl of the Articles of Religion of the Church of England. It is, however, hard to imagine the average FrenchCanadians being conversant with the nuances in meaning of of either of these sources. It is generally agreed that the word "Dominion" in reference to Canada was actually coined by a Canadian, Humphrey”s first cousin twice removed and Father of Confederation, Samuel Leonard Tilley (1818-1896), because Great Britain objected to the original proposal of Kingdom of Canada as potentially offensive to the U.S. Tilley took the word from the phrase in Psalm 72: "He shall have dominion from sea to sea. . .". There is, however, no question but that the Fathers of Confederation intended the term as a mark of respect to the British monarchy, and this caused resentments in Quebec. Although the term has largely been dropped from everyday speech and Canada Day replaces Dominion Day as the national holiday, the Dominion of Canada remains Canada's official name in the Constitution Act of 1982. See Eugene Forsey in the Canadian Encyclopedia (Edmonton: Hurtig, 1988), 612.

50. Although the traditional definition of "professional men" was doctor, lawyer and clergyman, my colleague Brian Young suggests in the Quebec context notary would have replaced clergyman.

51. This was clearly a sore point with the struggling novelist, who considered his work as a teacher undervalued. His ambition at this time was to make sufficient money to become a full-time author. He subsequently termed teachers "the most exploited, neglected and underprivileged class in Canada" in "The Thankless Profession," Canadian Home Journal (November, 1949), 29.

52. The published text differs significantly from the script at this point. Evidently Vaillancourt became confused by the erasures and was unsure of who said what. He attached this sentence and the four entries following to the preceding remarks of MacLennan. Thus MacLennan's intervention in the published text was as follows:

M: ". . . We have been no worse than some other countries; hut notwithstanding, our record in social security is something we ought to be ashamed of. Social conditions the world over were the basic causes of the present war, and I don't see how we can settle an issue of that magnitude this afternoon. However, it so happens that in Canada we have already something of a blue-print for Social Security. The Rowell-Sirois Report laid the groundwork for the beginning of a social security system in Canada:

H: Yes, l think it did ...".

53. The Report of the Royal Commission on DominionProvincial Relations, known as the Rowell-Sirois Report, was published in 1940.

54. It is quite likely that Humphrey could not bring himself to make this clearly false indication that the participants had come expecting to disagree, when they were working with a script. Despite the obvious staging he may have found it hypocritical to deliberately mislead listeners.

55. A.J. Hobbins, "René Cassin and the Daughter of Time," Fontanus Vol. Il (1989), 7-26.

56. J.P. Humphrey, "Whither Canada?", 44-45.

57. Henri Laugier (1883-1973) had been a pre-war Professor of Physiology at the Sorbonne. When France was overrun he went to the U.S., although he spoke no English. A teaching position was found for him at the Université de Montréal. In 1943, after the liberation of North Africa, he became Recteur at the University of Algiers, returning to France the following year.

58. Marie Marguerite Louise Landry (1896-1985) had studied art under Edwin Holgate and then Lyman. She held a number of exhibitions, including one with her daughter, Denyse. In 1919, she married a prominent lawyer, Émilien Gadbois. 